\title{
A REMS Scan-Based Report on Relation Between Body Mass Index and Osteoporosis in Urban Population of Medan at Royal Prima Hospital
}

\author{
Adrian Khu, ${ }^{1}$ Michael Sumardi ${ }^{2}$ \\ ${ }^{1}$ Department of Orthopaedic and Traumatology, Prima Indonesia University, Medan, Indonesia, \\ ${ }^{2}$ General Practitioner, Prima Indonesia University, Medan, Indonesia
}

\begin{abstract}
Body Mass Index (BMI) and osteoporosis are two major medical issues in practical life. Body Mass Index is recognized as an index to determine body fat mass while osteoporosis is a condition that decreases bone mass density and disrupts bone architecture, which will eventually affect bone strength and increase the risk of fracture. This study aimed to determine the relationship between BMI and osteoporosis using REMS. This was a cross-sectional study on 300 patients, 21 years of age and above, who underwent Radiofrequency Echographic Multi-Spectrometry (REMS) scan during October 2018 to September 2019 in Royal Prima Hospital, Medan, North Sumatra, Indonesia. Osteoporosis was defined based on densitometer parameters for spine and neck of femur while the BMI categories used were underweight $\left(<18.5 \mathrm{~kg} / \mathrm{m}^{2}\right)$, normal-weight $\left(18.5-22.9 \mathrm{~kg} / \mathrm{m}^{2}\right)$, overweight $\left(23-24.9 \mathrm{~kg} / \mathrm{m}^{2}\right)$, pre-obese (25-29.9 kg/m²), obese type 1 (BMI 30-40 kg/m²), and obese type $2(40.1-50 \mathrm{~kg} /$ $\mathrm{m}^{2}$ ). Correlation between osteoporosis and BMI was analyzed using Spearman correlation test. The median BMIs for Spine osteoporosis and Neck of Femur osteoporosis groups were 23.24 and 22.51, respectively. Meanwhile, the central tendency of the bone mass density $\left(\mathrm{gr} / \mathrm{cm}^{2}\right)$ of the spine and neck of femur osteoporosis were 0.70 and 0.53 , respectively. There was a significant correlation between BMI and the incidence of the neck of femur ( $R$ coefficient $=-0.690)$ and spine $(\mathrm{R}=-0.390)$ osteoporosis. Hence, lower BMI increases the potential of the neck of femur and spine osteoporosis.
\end{abstract}

Key words: Body mass index (BMI), osteoporosis, radiofrequency echographic multi-spectrometry (REMS)

\section{Laporan Berbasis Pemindaian REMS tentang Hubungan Antara Indeks Massa Tubuh dan Osteoporosis pada Penduduk Kota Medan di Rumah Sakit Royal Prima}

\begin{abstract}
Abstrak
Indeks Massa Tubuh (IMT) dan osteoporosis merupakan dua masalah medis utama dalam kehidupan seharihari. Indeks Massa Tubuh telah diakui sebagai indeks yang digunakan untuk menentukan massa lemak tubuh sementara osteoporosis merupakan kondisi yang menurunkan kepadatan tulang dan mengganggu arsitektur tulang yang pada akhirnya memengaruhi kekuatan tulang dan meningkatkan risiko fraktur. Penelitian ini bertujuan menentukan hubungan antara BI dan osteoporosis dengan menggunakan Radiofrequency Echographic Multi-Spectrometry (REMS). Penelitian ini merupakan penelitian potong lintang pada 300 pasien berusia 21 tahun ke atas yang menjalani pemindaian REMS selama periode Oktober 2018 sampai September 2019 di RS Royal Prima Medan. Osteoporosis ditentukan berdasarkan parameteri densitometri untuk tulang belakang dan leher femur sementara kategori BMI yang digunakan adalah berat badan (BB) kurang $(<18,5 \mathrm{~kg} / \mathrm{m} 2)$, BB normal$\left(18,5-22,9 \mathrm{~kg} / \mathrm{m}^{2}\right)$, BB berlebih (23-24,9 kg/m²), pra-obesitas (25-29.9 kg/m2), obesitas tipe 1 (BMI 30-40 kg/ $\mathrm{m} 2)$, dan obesitas tipe $2\left(40.1-50 \mathrm{~kg} / \mathrm{m}^{2}\right)$. Korelasi antara osteoporosis dan BMI dianalisis dengan menggunakan uji korelasi Spearman. Median IMT untuk osteoporosis pada tulang belakang dan leher femur adalah, secara berturut-turut, 23,24 dan 22,51. Terdapat perbedaan antara IMT dan insiden osteoporosis leher femur (R= $-0,690)$ dan tulang punggung $(\mathrm{R}=-0,390)$. Dengan demikian, IMT yang lebih rendah meningkatkan kemungkinan osteoporosis di leher femur dan tulang belakang.
\end{abstract}

Kata kunci: Indeks massa tubuh (IMT), osteoporosis, radiofrequency echographic multi-spectrometry (REMS)

Corresponding Author: Michael Sumadi, Prima Indonesia University, Medan, Jalan Belanga No. 1, Medan, North Sumatra, Indonesia, Email: michaelsumardi94@gmail.com 


\section{Introduction}

Bone mineral density (BMD) has many predisposition factors that serve as the substitute markers of bone strength. Of those, body mass index (BMI) is a strong predictor to determine osteoporosis. ${ }^{1}$ Osteoporosis is a condition where bone mass density decreases and bone architecture are disrupted thus affects bone strength, making it more prone to fractures. Osteoporosis is typically found in individuals with a bone mineral density (BMD) T-Score below normal (T-Score $\leq-2.5$ ). ${ }^{2}$

Osteoporosis is a silent disease without any distinctive signs until the patient experiences a fracture due to a minimum trauma. ${ }^{2,3}$ It is said to be the most frequent metabolic bone disorder, affecting approximately $28.7 \%$ of men and $32.3 \%$ of women in Indonesia. ${ }^{4}$ Several studies have reported that the prevalence rates of osteoporosis in women are $9 \%$ in the United Kingdom, 15\% in France and Germany, 16\% in the USA, and $38 \%$ in Japan. These are higher than in men, namely $1 \%$ in the United Kingdom, $4 \%$ in Japan, $3 \%$ in Canada, and 8\% in France. ${ }^{5}$

According to the International Osteoporosis Foundation, one in three women over the age of 50 has a risk of fracture due to osteoporosis while one in five men at the same age has the risk. Osteoporosis is undetected until a fracture happens. Parts of bone that often experience osteoporotic fractures are the spine, neck of femur, and distal radius bone. ${ }^{6}$ Osteoporosis leads to a decreased quality of life, increased disability life span, and create burdens to countries' health economic system. ${ }^{6}$ Because of the impacts, early osteoporosis diagnosis is essential. Osteoporosis is diagnosed by measurements of BMD in the lumbar spine and neck of the femur. Dual X-ray absorptiometry (DXA) is the reference technology to confirm osteoporosis diagnosis. In addition, an innovative echographic approach for osteoporosis diagnosis, which is referred to as the radiofrequency echographic multi-spectrometry (REMS), has been recently introduced and clinically validated through single-center studies. REMS has been shown to have significant correlations with respective BMD values and the proper DXA value of each parameter that is assumed as the gold standard reference. $^{7}$

Reports from several studies stated that bone density reduction is more often found in individuals with low BMI. ${ }^{7-10}$ According to a study by Fawzy ${ }^{8}$ in Ajman, there is a significant correlation statistically between BMD and low
BMI, which becomes an important risk factor in the incidence of low BMD.

Meanwhile, a study by Salamat ${ }^{9}$ in Iran proved that BMI is associated with the spine and neck of femur BMD and being overweight decreases the risk for osteoporosis.In Indonesia, Hendrijantini's research in Surabaya concluded that BMD significantly correlates with BMI (R coefficient $=-0.414, \mathrm{p}<0.05) .{ }^{10}$ Limbong's ${ }^{11}$ study in East Java supported this result by showing that women with a BMI of $<18.5$ have a 2.99 higher risk for osteoporosis than women with a BMI of $\geq 18.5$. Thus, BMI is deemed as a clinical risk factor for osteoporosis., ${ }^{912-14}$ This study aimed to determine the relationship between BMI and Osteoporosis using REMS.

\section{Methods}

This was a cross-sectional study that involves patients aged 21 years old and above who underwent Radiofrequency Echographic MultiSpectrometry (REMS) scan from October 2018 to September 2019 in Royal Prima Hospital, Medan, North Sumatra, Indonesia. Subjects were divided into normal, osteopenia, and osteoporosis based on the densitometry parameters. This study has been approved by the ethical committee under the ethical clearance number of 021/KEPK/ UNPRI/XII/2019. Subjects' BMI was classified into underweight $\left(<18.5 \mathrm{~kg} / \mathrm{m}^{2}\right)$, normal-weight $\left(18.5-22.9 \mathrm{~kg} / \mathrm{m}^{2}\right)$, overweight $\left(23-24.9 \mathrm{~kg} / \mathrm{m}^{2}\right)$, pre-obese $\left(25-29.9 \mathrm{~kg} / \mathrm{m}^{2}\right)$, obese type 1 (BMI $\left.30-40 \mathrm{~kg} / \mathrm{m}^{2}\right)$, and obese type $2(40.1-50 \mathrm{~kg} /$ $\mathrm{m}^{2}$ ).

REMS is a non-invasive approach without ionizing radiation for diagnosing osteoporosis. Densitometry parameters reported as the result of REMS include BMD $\left(\mathrm{gr} / \mathrm{cm}^{2}\right)$, Z-Score, and T-Score.

Spine scans were performed by putting transducer in a transabdominal position under the sternum to visualize L1 lumbar vertebra, then moving it down to the L4 lumbar vertebra. Spine scans lasted $80 \mathrm{~s}$ and were processed automatically in about 1-2 minutes. Meanwhile, the neck of femur scans were performed by placing the transducer parallel to the headneck axis of the femur in order to visualize the typical proximal femur, including the interfaces of the femoral head, neck, and trochanter. Neck of femur scans lasted $40 \mathrm{~s}$ and were processed automatically in about 1 minute. ${ }^{15}$

Subject characteristics and Densitometry Parameters were analyzed descriptively while 
the characteristics of the sample were compared to each other using Chi-Square Test for nonnumeric data. Mann-Whitney test was used as the non-parametric test and T-independent Test was used as the parametric test for numeric data. Furthermore, the analysis was followed by the Spearman correlation test to identify the correlation between BMI and bone osteoporosis (spine and neck of the femur bone).

\section{Results}

Three hundred subjects participated in this study. The following table showed the result of descriptive analysis for the subject characteristics.

Based on the Table 1, the average age of the subjects with a spine and neck of femur osteoporosis was 70.25 years old and 69.70 years old, respectively, and all of them were women. A

Table 1 Subject Characteristics by Density of Spine and Neck of Femur Bone

\begin{tabular}{|c|c|c|c|c|c|}
\hline Characteristics & Normal & p-value* & Osteopenia & p-value ${ }^{* *}$ & Osteoporosis \\
\hline \multicolumn{6}{|l|}{ Spine } \\
\hline $\begin{array}{l}\text { Age,Years Old }{ }^{* * *} \\
\text { [Median (IQR)] }\end{array}$ & $53(17.50)$ & $<0.01$ & $57(14)$ & $<0.01$ & $70.25(11)$ \\
\hline \multicolumn{6}{|l|}{ Sex $[N(\%)]$} \\
\hline Male & $25(56.8 \%)$ & \multirow{2}{*}{$<0.01$} & $18(14.4 \%)$ & \multirow{2}{*}{$<0.01$} & $0(0 \%)$ \\
\hline Female & $19(43.2 \%)$ & & $107(85.6 \%)$ & & $131(100 \%)$ \\
\hline Menopause [N (\%)] & $9(47.4 \%)$ & $<0.01$ & 77 (72\%) & $<0.01$ & $131(100 \%)$ \\
\hline \multicolumn{6}{|l|}{ BMI [N (\%)] } \\
\hline Underweight & $0(0 \%)$ & \multirow{6}{*}{$<0.01$} & $1(0.8 \%)$ & \multirow{6}{*}{$<0.01$} & $7(5.3 \%)$ \\
\hline Normal & $4(9.1 \%)$ & & $34(27.2 \%)$ & & $55(42 \%)$ \\
\hline Overweight & $4(9.1 \%)$ & & $23(18.4 \%)$ & & $25(19.1 \%)$ \\
\hline Pre-Obese & $20(45.5 \%)$ & & $41(32.8 \%)$ & & $34(26 \%)$ \\
\hline Obese Type 1 & $16(36.4 \%)$ & & $25(20 \%)$ & & $10(7.6 \%)$ \\
\hline Obese Type 2 & $0(0 \%)$ & & $1(0.8 \%)$ & & $0(0 \%)$ \\
\hline \multicolumn{6}{|c|}{ Neck of femur BMD [N (\%)] } \\
\hline Normal & $33(75 \%)$ & \multirow{4}{*}{$<0.01$} & $12(9.6 \%)$ & \multirow{4}{*}{$<0.01$} & $0(0 \%)$ \\
\hline Osteopenia & $11(25 \%)$ & & $104(83.2 \%)$ & & $21(16 \%)$ \\
\hline Osteoporosis & $0(0 \%)$ & & $9(7.2 \%)$ & & $110(84 \%)$ \\
\hline \multicolumn{4}{|l|}{ Neck of Femur } & & \\
\hline $\begin{array}{l}\text { Age,Years Old [Mean } \pm \\
\text { SD)] }\end{array}$ & $52.27 \pm 10.31$ & $<0.01$ & $59.02 \pm 12.00$ & $<0.01$ & $69.70 \pm 9.45$ \\
\hline \multicolumn{6}{|l|}{$\operatorname{Sex}[N(\%)]$} \\
\hline Male & $19(42.2 \%)$ & \multirow{2}{*}{$<0.01$} & $24(17.6 \%)$ & \multirow{2}{*}{$<0.01$} & $0(0 \%)$ \\
\hline Female & $26(57.8 \%)$ & & $112(82.4 \%)$ & & $119(100 \%)$ \\
\hline Menopause [N (\%)] & $18(69.2 \%)$ & $<0.01$ & $82(73.2 \%)$ & $<0.01$ & 117 (98.3\%) \\
\hline \multicolumn{6}{|l|}{ BMI [N (\%)] } \\
\hline Underweight & $0(0 \%)$ & \multirow{6}{*}{$<0.01$} & $0(0 \%)$ & \multirow{6}{*}{$<0.01$} & $8(6.7 \%)$ \\
\hline Normal & $0(0 \%)$ & & 33 (24.3\%) & & $60(50.4 \%)$ \\
\hline Overweight & $1(2.2 \%)$ & & $26(19.1 \%)$ & & $25(21 \%)$ \\
\hline Pre-Obese & $18(40 \%)$ & & $54(39.7 \%)$ & & 23 (19.3\%) \\
\hline Obese Type 1 & $25(55.6 \%)$ & & $23(16.9 \%)$ & & $3(2.5 \%)$ \\
\hline Obese Type 2 & $1(2.2 \%)$ & & $0(0 \%)$ & & $0(0 \%)$ \\
\hline \multicolumn{6}{|l|}{ Spine BMD [N (\%)] } \\
\hline Normal & $33(73.3 \%)$ & \multirow{3}{*}{$<0.01$} & $11(8.1 \%)$ & \multirow{3}{*}{$<0.01$} & $0(0 \%)$ \\
\hline Osteopenia & $12(26.7 \%)$ & & $104(76.5 \%)$ & & $9(7.6 \%)$ \\
\hline Osteoporosis & $0(0 \%)$ & & $21(15.4 \%)$ & & $110(92.4 \%)$ \\
\hline
\end{tabular}

${ }^{*}$ Comparison between Normal and Osteoporosis Group. ${ }^{* *}$ Comparison between Osteopenia and Osteoporosis Group. *** Comparison was analyzed by Mann-Whitney 
Table 2 Densitometry Parameter of Spine and Neck of Femur Bone

\begin{tabular}{lccc}
\hline \multicolumn{1}{c}{$\begin{array}{c}\text { Densitometry } \\
\text { Parameter }\end{array}$} & $\begin{array}{c}\text { Normal } \\
{[\text { Median (IQR)] }}\end{array}$ & $\begin{array}{c}\text { Osteopenia } \\
{[\text { Median (IQR)] }}\end{array}$ & $\begin{array}{c}\text { Osteoporosis } \\
{[\text { Median (IQR)] }}\end{array}$ \\
\hline Spine & $0.96 \pm 0.18$ & & \\
BMD $\left(\mathrm{gr} / \mathrm{cm}^{3}\right)^{*}$ & $-0.80(0.30)$ & $-2.10(0.45)$ & $-3.00 \pm 0.05$ \\
T Score & $0.30(0.35)$ & $-0.70(0.80)$ & $-1.00(0.50)$ \\
Z Score & & & \\
Neck of Femur & $0.85(0.07)$ & $0.63(0.08)$ & $0.53(0.10)$ \\
BMD (gr/cm $\left.{ }^{3}\right)$ & $0.00(0.65)$ & $-2.00(0.70)$ & $-2.90(0.90)$ \\
T Score & $1.00(0.60)$ & $-0.60(1.10)$ & $-1.20(0.70)$ \\
Z Score &
\end{tabular}

*Data is expressed as Mean \pm SD

higher number of women were found to have spine osteoporosis (131 patients) compared to those with neck of femur osteoporosis (119 patients). Most of these women were in their menopause $198.3 \%$ in the group with neck of femur osteoporosis and $100 \%$ in the group with spine osteoporosis).

From the perspective of the BMI, most subjects who suffered from spine osteoporosis were preobese $(26 \%)$ with few underweight subjects $(5.3 \%)$, while most subjects who suffered from

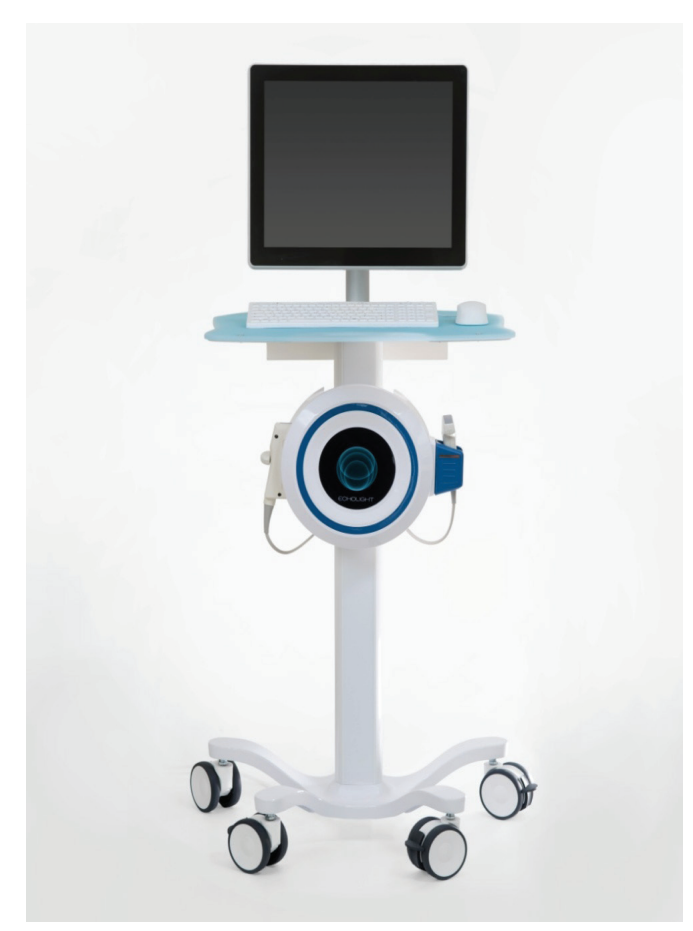

Figure Radiofrequency Echographic MultiSpectrometry (REMS) neck of femur osteoporosis were overweight (21\%) with few underweight subjects (6.7\%).

Based on the BMD of subjects in the table, neither the spine nor neck of femur osteoporosis showed comorbid conditions on other bones. From 131 patients who suffered from spine osteoporosis $16 \%$ also suffered from the neck of femur osteopenia and the remaining 84\% suffered from the neck of femur osteoporosis. Meanwhile, of the 119 patients suffered from the neck of femur osteoporosis $7.6 \%$ also suffered from spine osteopenia and the remaining $92.4 \%$ suffered from spine osteoporosis.

It was revealed that the tendency of BMD, T Score, and Z score for Spine osteoporosis subjects were $0.70 \mathrm{gr} / \mathrm{cm}^{3},-3$, and -1 , respectively, while

Table 3 Correlation of Neck of femur Osteoporosis and BMI based on Spearman Correlation Test Results

\begin{tabular}{lccc}
\hline $\begin{array}{c}\text { Neck of } \\
\text { femur BMD }\end{array}$ & $\begin{array}{c}\text { BMI }\left(\mathrm{kg} / \mathbf{m}^{2} \text { ) }\right. \\
\text { [Median } \\
\text { (IQR)] }\end{array}$ & P-value & R \\
\hline Normal & $30.84(5.43)$ & & \\
Osteopenia & $25.58(5.71)$ & $<0.01$ & -0.690 \\
Osteoporosis & $22.51(4.19)$ & & \\
\hline
\end{tabular}

Table 4 Correlation between Spine Osteoporosis and BMI based on Spearman Correlation Test Results

\begin{tabular}{lccc}
\hline Spine BMD & $\begin{array}{c}\text { BMI }\left(\mathrm{kg} / \mathrm{m}^{2} \text { ) }\right. \\
\text { [Median } \\
\text { (IQR)] }\end{array}$ & P-Value & R \\
\hline Normal & $28.09(6.84)$ & & \\
Osteopenia & $25.48(6.45)$ & $<0.01$ & -0.390 \\
Osteoporosis & $23.24(5.25)$ & & \\
\hline
\end{tabular}


the medians of BMD, $\mathrm{T}$ Score, and $\mathrm{Z}$ score for Neck of femur osteoporosis were $0.53 \mathrm{gr} / \mathrm{cm}^{3}$, -2.90 , and -1.20 , respectively. The results of the Spearman correlation were shown in the following tables.

A significant correlation between the Neck of femur bone density and BMI (P-value <0.05) was identified with a decrease in BMI led to an increase in potential neck of femur osteoporosis. The correlation between Spine Osteoporosis and BMI was shown in the table below. A significant correlation between spine osteoporosis and BMI (P-value $<0.05$ ) and a decrease of BMI led to an increase in potential spine osteoporosis.

The $\mathrm{R}$ coefficient values of the spine and neck of femur osteoporosis and BMI were 0.390 and -0.690 , respectively. This means that the correlation between the BMI and spine osteoporosis was weaker than the correlation between neck of femur osteoporosis and BMI.

\section{Discussion}

The statistical analyses in this study reveals that the social-demography (age, sex, and BMI) factors affect the incidence of osteoporosis and osteopenia of the spine and the neck of femur. On the other hand, the BMD of the spine affects the neck of femur, and vice versa. The BMD of the neck of femur $\left(0.70 \mathrm{gr} / \mathrm{cm}^{3}\right)$ was less than the BMD of the spine $\left(0.53 \mathrm{gr} / \mathrm{cm}^{3}\right)$. Furthermore, the analysis of the correlation between BMD and BMI shows that there is an inverse correlation between BMD and BMI.

The bone density was evaluated by Radiofrequency Echographic MultiSpectrometry (REMS) in this study. REMS represents an innovative echographic approach for the diagnosis of osteoporosis, which is directly applicable to both the spine and the neck of femur. BMD, as one of the main result parameter of this non-ionizing technique, is a diagnostic index that is expressed in gram $/ \mathrm{cm}^{2} .7$

REMS scans of the spine and the neck of femur were performed using Echolight equipped with a convex transducer operating at $3.5 \mathrm{MHz}$ frequency. Echolight integrates a normative reference database (National Health and Nutrition Examination Survey, NHANES) with derived T-Score and Z-score values. ${ }^{7,15}$

According to a study by Paola in Italy, 2018, there has been a good agreement between REMS outcome and DXA (Gold Standard for osteoporosis diagnosis) outcome, with the average differences of spine BMD of $-0.004 \pm 0.088$ gram $/ \mathrm{cm}^{2}$ and
$-0.006 \pm 0.076 \mathrm{gram} / \mathrm{cm}^{2}$ for femur

Namwongprom $^{16}$ from Thailand in 2012 reported that there is a significant correlation between the bone density of the neck of femur and body composition among premenopausal women. This is similar to the results from Gholami ${ }^{17}$ in a study conducted in Iran in 2013 suggesting that in postmenopausal subjects, a lean body mass is a strong predictor of osteoporosis.Widyanti's ${ }^{18}$ study in Bandung also showed that there is a positive correlation between the bone density of neck of femur and body fat.

There is a significant correlation between BMI and Osteoporosis. Lower BMI increases the risk of osteoporosis due to the poor nutritional state that could result in decreasing bone density. ${ }^{19}$ Furthermore, a high BMI has a linear correlation with a high BMD because of the conversion of androgen into estrogen, which increases bone mass in both men and women. ${ }^{9}$

There are few limitations in this study including the age range of the subjects of 40-80 years old, the unequal proportion of female and male samples, and the lack of BMI samples in the underweight category.

\section{References}

1. Hoxha R, Islami H, Qorraj-Bytyqi H, Thaci S, Bahtiri E. Relationship of weight and body mass index with bone mineral density in adult men from Kosovo. Mater Socio Medica. 2014;26(5):306-8. doi:10.5455/ msm.2014.26.306-308

2. Indonesia Health Ministry. Osteoporosis Management Guidelines. Jakarta: Indonesia Health Ministry; 2008.

3. Mithal A. The Asian audit: epidemiology, costs and burden of osteoporosis in Asia 2009. Stenmark J, Nauroy L, ed. New Delhi: International Osteoporosis Foundation; 2009.

4. US Department of Health and Human Services. Bone health and osteoporosis: a report of the Surgeon General. US Heal Hum Serv. 2004. doi:10.2165/00002018200932030-00004

5. Tian L, Yang R, Wei L, Liu J, Yang Y, Shao F, et al. Prevalence of osteoporosis and related lifestyle and metabolic factors of postmenopausal women and elderly men. Medicine (Baltimore). 2017;96(43):e8294.

6. Sozen T, Ozisik L, Calik Basaran N. An overview and management of osteoporosis. 
Eur J Rheumatol. 2017;4(1):46-56.

7. Di Paola M, Gatti D, Viapiana O, Cianferotti L, Cavalli L, Caffarelli C, et al. Radiofrequency echographic multispectrometry compared with dual X-ray absorptiometry for osteoporosis diagnosis on lumbar spine and femoral neck. Osteoporos Int. 2019;30(2): 391-402.

8. Fawzy T, Muttappallymyalil J, Sreedharan J, Ahmed A, Alshamsi SO, Al Ali MS, et al. Association between body mass index and bone mineral density in patients referred for dual-energy x-ray absorptiometry scan in Ajman, UAE. J Osteoporos. 2011;2011:876309. doi: 10.4061/2011/ 876309.

9. Salamat MR, Salamat AH, Abedi I, Janghorbani M. Relationship between weight, body mass index, and bone mineral density in men referred for dual-energy X-ray absorptiometry scan in Isfahan, Iran. Hindawi Publ Corp. 2013;2013(205963):17. doi:10.1155/2013/205963.

10. Hendrijantini N, Alie R, Setiawati R, Astuti ER, Wardhana M. The correlation of bone mineral density (BMD), body mass index (BMI) and osteocalcin in postmenopausal women. Biol Med (Aligarh) 2016;8(6):1-5. doi:10.4172/0974-8369.1000319.

11. Limbong EA, Syahrul F. Rasio risiko osteoporosis menurut indeks massa tubuh, paritas, dan konsumsi kafein. J Berk Epidemiol. 2015;3(2):194-204.

12. Salter RB. Textbook of disorders and injuries of the musculoskeletal system. 3th ed. Baltimore: Wiliam \& Wilkins; 1990.

13. Nguyen TV, CenterJR, EismanJA. Osteoporosis in elderly men and women: effects of dietary calcium, physical activity, and body mass index. J Bone Miner Res. 2010;15(2):322-31. doi:10.1359/jbmr.2000.15.2.322.

14. Kanis JA, McCloskey EV, Johansson $H$, Cooper C, Rizzoli R, Reginster JY. European guidance for the diagnosis and management of osteoporosis in postmenopausal women. Osteoporos Int. 2013;24(1):23-57. doi:10.1007/s00198-012-2074-y.

15. Conversano F, Franchini R, Greco A, Soloperto G, Chiriacò F, Casciaro E, et al. A Novel ultrasound methodology for estimating spine mineral density. Ultrasound Med Biol. 2015;41(1):281-300. doi:10.1016/j. ultrasmedbio.2014.08.017.

16. Namwongprom S, Rojanasthien $S$, Mangklabruks A, Soontrapa S, Wongboontan C, Ongphiphadhanakul B. Effect of fat mass and lean mass on bone mineral density in postmenopausal and perimenopausal Thai women. Int J Womens Health. 2013;5(1):8792. doi:10.2147/IJWH.S41884.

17. Gholami M, Ghassembaglou N, Nikbakht $\mathrm{H}$, Eslamian F. The relationship between body composition and osteoporois in postmmenopausal women. J Food Technol Nutr. 2013;4(40):55-64.

18. LRE Widyanti, Kusumastuty I, Putri Arfiani E. Hubungan komposisi tubuh dengan kepadatan tulang wanita usia subur di Kota Bandung. Indones J Hum Nutr. 2017;4(1):2333. doi:10.21776/ub.ijhn.2017.004.01.3.

19. Kim YS, Han JJ, Lee J, Choi HS, Kim JH, Lee $\mathrm{T}$. The correlation between bone mineral density/trabecular bone score and body mass index, height, and weight. Osteoporos sarcopenia. 2017;3(2):98-103. doi:10.1016/j.afos.2017.02.001 